\title{
Description of a new genus and species of Chrysopetalidae (Annelida: Polychaeta) from the NE Atlantic, with some further records of related species
}

\author{
Ascensão RAVARA ${ }^{1, *}$, M. Teresa AGUADO $^{2}$, Clara F. RODRIGUES ${ }^{3}$, \\ Luciana GÉNIO $^{4}$ \& Marina R. CUNHA ${ }^{5}$ \\ 1,3,4,5 Departamento de Biologia \& CESAM, Universidade de Aveiro, 3810-193 Aveiro, Portugal. \\ ${ }^{2}$ Animal Evolution and Biodiversity, Johann-Friedrich-Blumenbach Institute for Zoology \\ and Anthropology, Georg-August-Universität, 37073 Göttingen, Germany. \\ ${ }^{2}$ Centro de Investigación en Biodiversidad y Cambio Global (CIBC-UAM), Departamento \\ de Biología, Universidad Autónoma de Madrid, Cantoblanco, 28049 Madrid, Spain. \\ *Corresponding author: aravara@ua.pt \\ 22Email: maite.aguado@uam.es \\ ${ }^{3}$ Email: clara.rodrigues@ua.pt \\ ${ }^{4}$ Email:1.genio@ua.pt \\ ${ }^{5}$ Email: marina.cunha@ua.pt \\ ${ }^{1}$ urn:1sid:zoobank.org:author:677F8AB4-7FD3-483A-A047-C4BD5A6A449D
${ }^{2}$ urn:1sid:zoobank.org:author:F9D27435-8C88-4785-A980-A3B07C41DD22
${ }^{3}$ urn:lsid:zoobank.org:author:D54DAA7A-BE73-4E37-B5A1-760517AF1BA5
${ }^{4}$ urn:1sid:zoobank.org:author:3E6080EC-1249-459C-B368-D621FB641D47
${ }^{5}$ urn:lsid:zoobank.org:author:553A98B5-0AE0-424F-9ED5-EC50F129519C
}

\begin{abstract}
Five chrysopetalid species are reported from samples collected at bathyal depths in three NE Atlantic regions: the Bay of Biscay, the Horseshoe Abyssal Plain and the Gulf of Cadiz. Arichlidon reyssi (Katzmann et al., 1974), Dysponetus caecus (Langerhans, 1880) and D. profundus Böggemann, 2009 are free-living forms found mainly on biogenic substrates (e.g., coral and sunken wood). A brief description and taxonomical remarks are given for each of these species and their geographical distributions and habitat records were updated accordingly. Natsushima bifurcata Miura \& Laubier, 1990 and Craseoschema thyasiricola gen. et sp. nov. are symbionts inhabiting the mantle cavity of chemosynthesis-based bivalves known from four mud volcanoes from the Gulf of Cadiz. Craseoschema thyasiricola gen. et sp. nov. was found inside a thyasirid bivalve and presents mixed morphological characteristics of free-living and symbiotic forms within Calamyzinae Hartmann-Schröder, 1971. A full description of the new species is given together with DNA sequences of the genes COI, 16S and H3 that were used in a phylogenetic analysis to indicate the position of the new genus within the family.
\end{abstract}

Keywords. Deep-sea, Bay of Biscay, Horseshoe Abyssal Plain, Gulf of Cadiz, symbiotic species.

Ravara A., Aguado M.T., Rodrigues C.F., Génio L. \& Cunha M.R. 2019. Description of a new genus and species of Chrysopetalidae (Annelida: Polychaeta) from the NE Atlantic, with some further records of related species. European Journal of Taxonomy 539: 1-21. https://doi.org/10.5852/ejt.2019.539 


\section{Introduction}

Chrysopetalidae Ehlers, 1864 is an ecologically complex family of marine worms currently comprising more than 80 species (Read \& Fauchald 2018; Watson \& Faulwetter 2017), the majority of which are allocated to three subfamilies, Chrysopetalinae Ehlers, 1864, Dysponetinae Aguado et al., 2013 and Calamyzinae Hartmann-Schröder, 1971 (Aguado et al. 2013). Most chrysopetalids are free-living forms inhabiting all depths, usually on hard substrates such as coral reefs, rock and shell debris (Watson Russell 2000a). In the past two decades, several new species belonging to Chrysopetalinae and Calamyzinae have been described from reducing habitats such as hydrothermal vents, cold seeps, wood- and whalefalls and organic-enriched sediments (e.g., Watson Russell 2001; Dahlgren et al. 2004; Wiklund et al. 2009; Aguado \& Rouse 2011; Watson et al. 2016). Apart from the free-living forms, the subfamily Calamyzinae includes 21 symbiotic species (sensu Martin \& Britayev 1998, 2018) of which one is an external parasite, the monotypic genus Calamyzas Arwidsson, 1932, and the others, formerly known as Nautiliniellidae Miura \& Laubier, 1990, are commensals. The majority of the known commensal species are obligate symbionts living in the mantle cavity, often on the gill lamellae, of deep-sea chemosynthetic bivalves of the families Vesicomyidae Dall \& Simpson, 1901, Mytilidae Rafinesque, 1815, Solemyidae Gray, 1840 and Thyasiridae Dall, 1900 (Martin \& Britayev 1998, 2018; Dreyer et al. 2004; Sellanes et al. 2008; Aguado \& Rouse 2011). Recently, a new symbiotic species was described living on the body surface of an octopus (Jimi et al. 2019). In contrast with the more mobile free-living forms, symbiotic species have strongly modified neurochaetae and most of them lack notochaetae, anal cirri and jaws, as an adaptation to a symbiotic lifestyle.

The present study reports the occurrence of free-living and symbiotic chrysopetalid polychaetes from bathyal depths in three geographic areas located mostly on the Atlantic Iberian margin. The geographic and bathymetric distributions of the species are extended and discussed. A new symbiotic genus and species is described within the subfamily Calamyzinae. DNA sequences for the new species are given and a phylogenetic analysis indicating its position within the family is presented.

\section{Material and methods}

The chrysopetalid specimens studied herein were obtained from three NE Atlantic regions, the Bay of Biscay, the Horseshoe Abyssal Plain and the Gulf of Cadiz (Fig. 1), under the framework of several international projects (Table 1). All the biological material is preserved in $96 \%$ ethanol.

\section{Morphological analyses}

Morphological observations were carried out with an Olympus stereo microscope equipped with a camera lucida for line drawings. Body length includes prostomium appendages and chaetae. Stereo microscope images were taken with a Canon EOS1100D camera. Compound microscope images were obtained with a Zeiss Axioplan 2 imaging light microscope (Carl Zeiss, Oberkochen, Germany), equipped with a DP70 Olympus camera (Olympus Corp., Tokyo, Japan). Specimens used for scanning electron microscopy (SEM) were transferred to $100 \%$ ethanol, critical point dried, mounted on aluminium stubs, sputtercoated with gold-palladium (Polaron E500) for 2 minutes and imaged using a TM3030Plus tabletop microscope (Hitachi). The holotype of the newly described species is deposited in the Natural History Museum of London (NHMUK). The remaining chrysopetalid material examined during this study is deposited in the Biological Research Collection of Marine Invertebrates of the Department of Biology of the University of Aveiro (DBUA).

\section{Molecular analysis}

For the sequences of Craseoschema thyasiricola gen. et sp. nov., DNA was extracted using $50 \mu 1$ of QuickExtract ${ }^{\mathrm{TM}}$ DNA Extraction Solution (Epicenter products). A small piece of tissue was placed in the solution and incubated at $65^{\circ} \mathrm{C}$ for $30 \mathrm{~min}$ followed by $5 \mathrm{~min}$ at $95^{\circ} \mathrm{C}$ and then 
stored at $-20^{\circ} \mathrm{C}$. Approximately $691 \mathrm{bp}$ of COI, $314 \mathrm{bp}$ of $16 \mathrm{~S}$ and $364 \mathrm{bp}$ of $\mathrm{H} 3$ were amplified using the primers polyLCO (GAYTATWTTCAACAAATCATAAAGATATTGG) and polyHCO (TAMACTTCWGGGTGACCAAARAATCA) (Carr et al. 2011) for COI, AnnF (GCG GTA TCC TGA CCG TRC WAA GGT A) and AnnR (TCC TAA GCC AAC ATC GAG GTG CCA A) (Sjölin et al. 2005) for 16S, and H3F (ATG GCT CGT ACC AAG CAG ACV GC) and H3R (ATA TCC TTR GGC ATR ATR GTG AC) (Colgan et al. 2000) for H3. PCR mixtures contained $20 \mu \mathrm{l}$ of double distilled $\mathrm{H}_{2} \mathrm{O}$, $1 \mu \mathrm{l}$ of each primer $(10 \mu \mathrm{M}), 3 \mu \mathrm{l}$ of DNA template and puReTaq Ready-To-Go PCR Beads (Amersham Biosciences). Supreme NZYTaq DNA polymerase (NZYTech) was used for difficult sequences, in a mixture of $8.5 \mu \mathrm{l}$ of double distilled $\mathrm{H}_{2} \mathrm{O}, 1 \mu \mathrm{l}$ of each primer $(10 \mu \mathrm{M}), 2 \mu \mathrm{l}$ of DNA template and $12.5 \mu \mathrm{l}$ of taq buffer. The temperature profiles were as follows: $96{ }^{\circ} \mathrm{C} / 4 \mathrm{~min}, 45$ cycles of

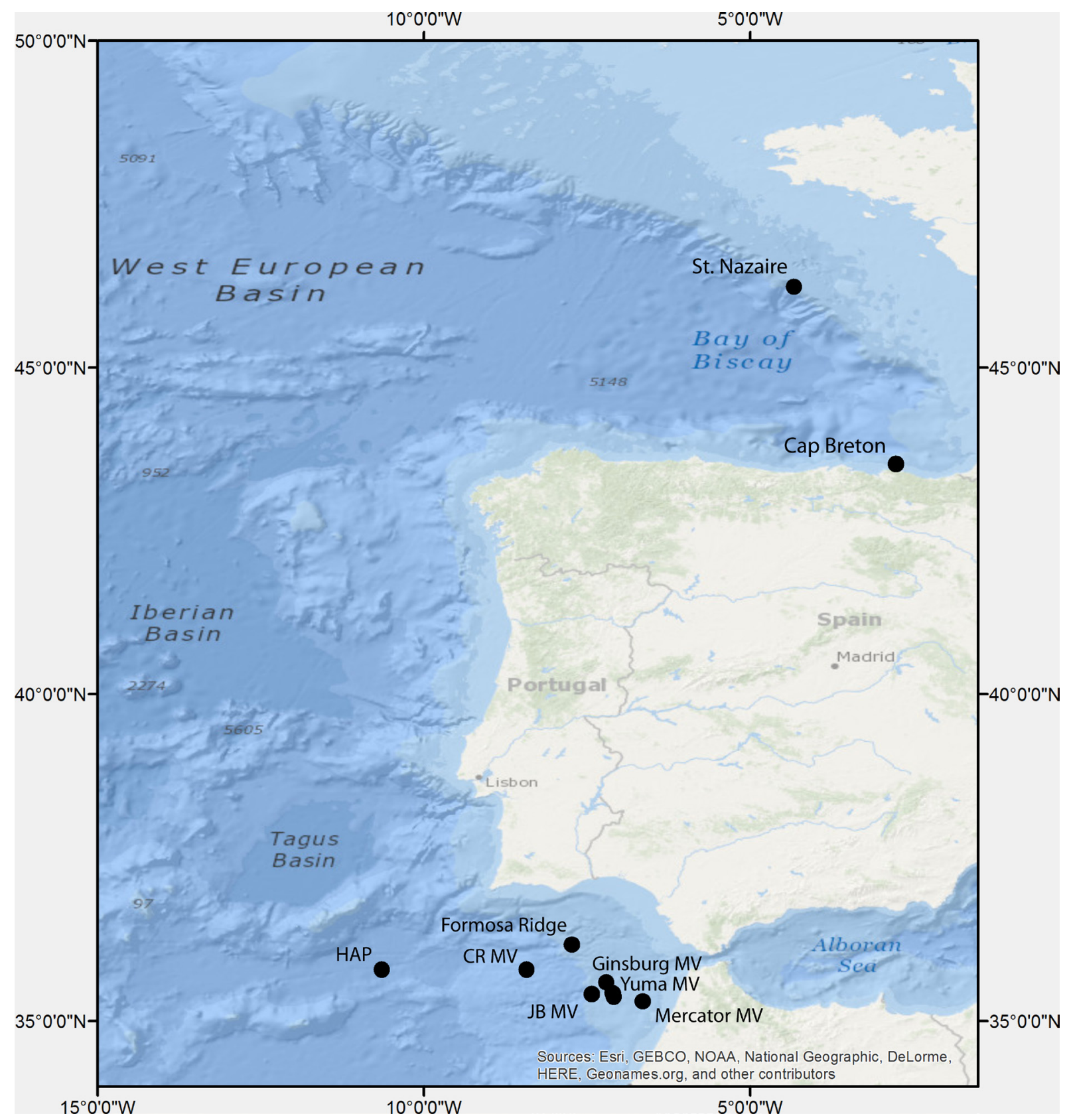

Fig. 1. Map with the locations of the sampling sites. $\mathrm{CR}=$ Carlos Ribeiro; HAP $=$ Horseshoe Abyssal Plain; JB = Jezus Baraza; MV = mud volcano. 


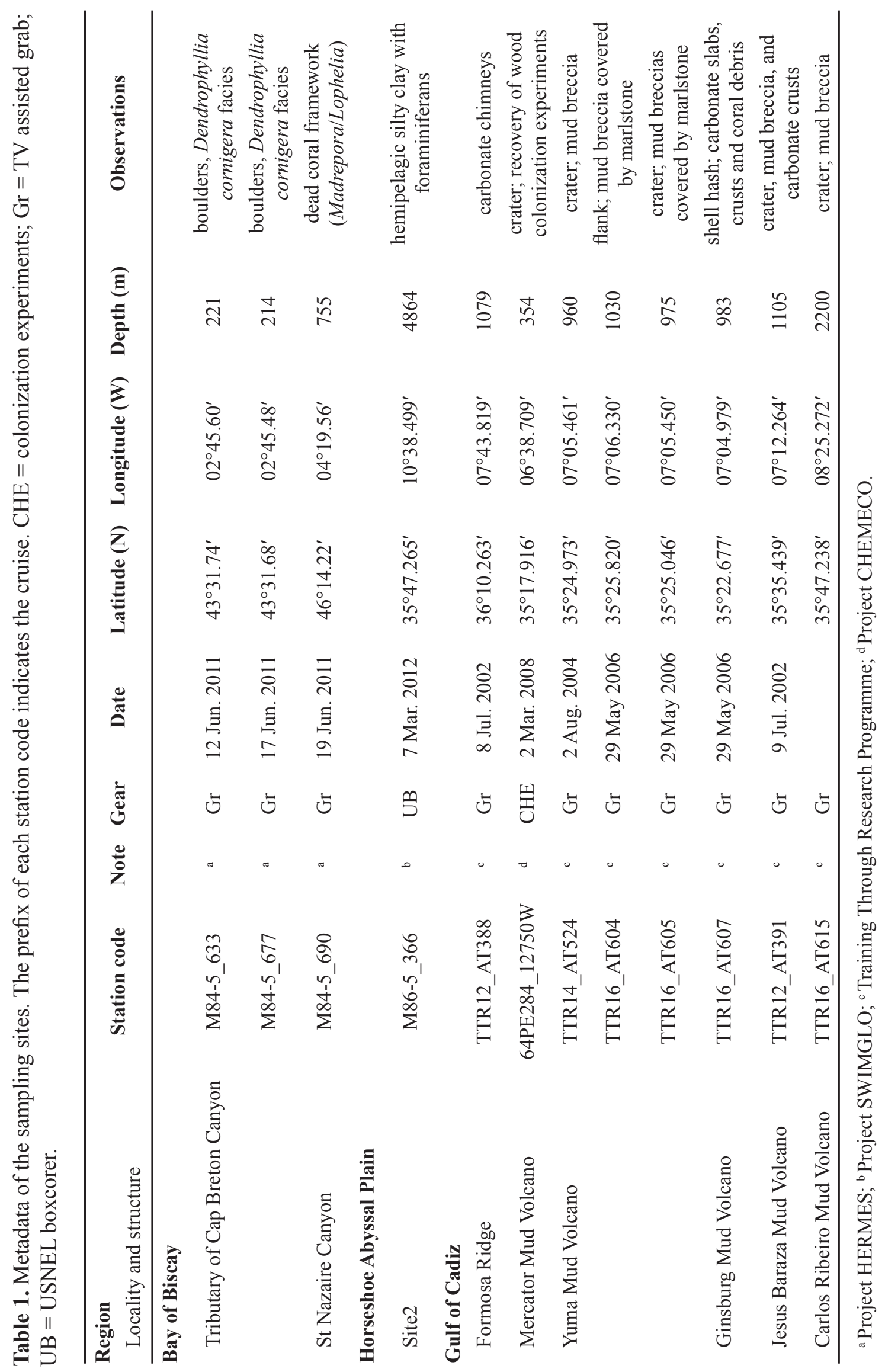


$94^{\circ} \mathrm{C} / 30 \mathrm{~s}, 48^{\circ} \mathrm{C} / 30 \mathrm{~s}$ and $72^{\circ} \mathrm{C} / 60 \mathrm{~s}$, followed by $72^{\circ} \mathrm{C} / 8 \mathrm{~min}$ for COI, $96^{\circ} \mathrm{C} / 90 \mathrm{~s}, 35$ cycles of $94^{\circ} \mathrm{C} / 40 \mathrm{~s}, 60^{\circ} \mathrm{C} / 40 \mathrm{~s}$ and $72^{\circ} \mathrm{C} / 45 \mathrm{~s}$, followed by $72^{\circ} \mathrm{C} / 7 \mathrm{~min}$ for $16 \mathrm{~S}$ and $94^{\circ} \mathrm{C} / 90 \mathrm{~s}, 35$ cycles of $94^{\circ} \mathrm{C} / 40 \mathrm{~s}, 53^{\circ} \mathrm{C} / 40 \mathrm{~s}$ and $72^{\circ} \mathrm{C} / 45 \mathrm{~s}$, followed by $72^{\circ} \mathrm{C} / 7 \mathrm{~min}$ for $\mathrm{H} 3$. PCR products were purified with a QIAquick PCR Purification Kit (Qiagen). The sequencing was performed by the Macrogen Sequencing System in Madrid. Overlapping sequence fragments were merged into consensus sequences and aligned using GENEIOUS ver. 4.7.6, available from http://www.geneious.com/, with default settings. All viable sequences were deposited in GenBank.

\section{Sequences}

COI, H3, $16 \mathrm{~S}$ and $18 \mathrm{~S}$ sequences for 22 chrysopetalid species, belonging to all three subfamilies, and sequences of five other polychaete families (outgroup taxa) were included in this study. The GenBank accession numbers of these sequences are presented in Table 2. In Genbank, there are currently two 18S sequences available from two specimens of Micospina auribohnorum Watson et al., 2016. The first one (voucher SIO A1427, GenBank acc. $n^{\circ}$ JX078941.1) comes from Costa Rica and was sequenced by Aguado et al. (2013), while the second (SIO A3640, GenBank acc. $\mathrm{n}^{\circ} \mathrm{KU}$ 057928) is from California and was sequenced by Watson et al. (2016). Watson et al. (2016) considered the sequence JX078941.1 chimeric, with the first part being correct but the second part belonging to Calamyzas amphictenicola Arwidsson, 1932 (GenBank acc $n^{\circ}$ JX078939). They truncated the sequence and updated it in GenBank with the acc. $\mathrm{n}^{\circ} \mathrm{JX} 078941.2$. However, a contamination was not possible since the C. amphictenicola and M. auribohnorum sequences in Aguado et al. (2013) were obtained in different laboratories. Additionally, the sequence JX078941.1 is not significantly more similar to $C$. amphictenicola than to other calamyzins. In contrast, the sequence KU057928 provided by Watson et al. (2016) blasts with Siboglinidae Caullery, 1914, showing 95\% similarity. Additionally, Watson et al. (2016) erroneously marked the sequences of M. auribohnorum (SIO A1427) in bold in their table 1 to indicate that they had sequenced them (see Watson et al. 2016: caption of table 1). Those sequences were previously obtained by Aguado et al. (2013). In our analyses, we included the 18S of M. auribohnorum (JX078941.1) as originally submitted by Aguado et al. (2013) and excluded the one provided by Watson et al. (2016) (KU057928), since it does not belong to Calamyzinae.

\section{Phylogenetic analyses}

Sequences of four molecular markers (COI, H3, 16S and 18S) were included in the phylogenetic analysis. Alignments of ortholog partitions were performed using the program Mafft (Katoh et al. 2002) with the default parameters. A concatenation of the partitions (18S, 16S, H3 and COI) for the combined data set was conducted with FASconCAT-G (Kück \& Longo 2014). Maximum likelihood analyses of the four markers independently and the concatenated data set $(\mathrm{COI}+\mathrm{H} 3+16 \mathrm{~S}+18 \mathrm{~S})$, respectively, were conducted using RAxML ver. 8.1.3 (Stamatakis 2014), with the GTR $+\mathrm{I}+\mathrm{G}$ model, as GTR is the only available nucleotide model in this program. Bootstrap support values were generated with a rapid bootstrapping algorithm (Stamatakis et al. 2008) for 1000 replicates in RAxML.

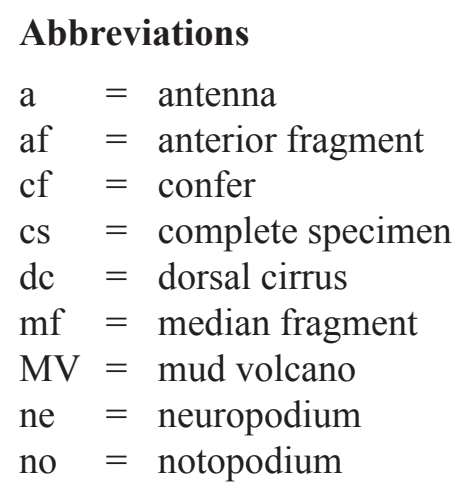


Table 2. Sequenced specimens and GenBank accession numbers. GB = sequences obtained from NCBI GenBank; SIO = Scripps Institution of Oceanography; $\mathrm{MB}=$ Museu Nacional de História Natural de Lisboa (Museu Bocage); DBUA = Research Collection of Marine Invertebrates, Dep. Biologia, Universidade de Aveiro; ANEA NHMUK = Natural History Museum, London, UK; - = missing data.

\begin{tabular}{|c|c|c|c|c|c|}
\hline Terminal & Voucher & $18 S$ & $16 S$ & COI & H3 \\
\hline \multicolumn{6}{|l|}{ CHRYSOPETALIDAE } \\
\hline \multicolumn{6}{|l|}{ Calamyzinae } \\
\hline Boudemos ardabilia & GB & EU555042 & EU555051 & EU555052 & JX078959 \\
\hline Boudemos flokati & GB & EU555043 & EU555034 & EU555065 & - \\
\hline Calamyzas amphictenicola & SIO A3274 & JX078939 & JX093563 & JX078956 & JX078967 \\
\hline Calamyzinae sp. & SIO A3410 & - & JX078951 & JX078957 & JX078963 \\
\hline Craseoschema thyasiricola & $\begin{array}{c}\text { ANEA NHMUK } \\
2019.7339\end{array}$ & - & MK988419 & MK988420 & MK988421 \\
\hline Iheyomytilidicola lauensis & SIO A2267 & JX078942 & JX078952 & JF304502 & JX078966 \\
\hline Laubierus alvini & SIO A1500 & JX078940 & JX078950 & JF304494 & JX078964 \\
\hline Micospina auribohnorum & SIO A1427 & JX078941 & JX078949 & JX093564 & JX078965 \\
\hline Natsushima bifurcata & MB29-000186 & JX078943 & JX078953 & JF304492 & JX078960 \\
\hline Natsushima sashai & SIO A1619 & JX078944 & JX078954 & JF304496 & JX078961 \\
\hline Shinkai fontefridae & SIO A2204 & - & JX078948 & JF304499 & - \\
\hline Shinkai longipedata & SIO A2283 & JX078945 & - & JF304500 & JX078962 \\
\hline Spathochaeta octopodis & GB & - & LC381961 & LC381959 & LC381960 \\
\hline $\begin{array}{l}\text { Vigtorniella zaikai } \\
\text { Chrysopetalinae }\end{array}$ & SIO $5639-40$ & KU057929 & KU057933 & KU057939 & KU057936 \\
\hline Arichlidon reyssi & GB & EU555036 & EU555045 & EU555054 & - \\
\hline Chrysopetalidae sp. & GB & AY176284 & - & - & - \\
\hline Chrysopetalum debile & GB & EU555037 & EU555046 & AF221567 & - \\
\hline Palaequor heterosetosa & GB & EU555035 & EU555044 & EU555053 & - \\
\hline \multicolumn{6}{|l|}{ Dysponetinae } \\
\hline Dysponetus bulbosus & SIO A4696 & JX078946 & DQ442570 & JQ623501 & - \\
\hline Dysponetus caecus & GB & AY839568 & EU555047 & AF221568 & - \\
\hline Dysponetus caecus 2 & GB & - & GQ426603 & - & - \\
\hline Dysponetus populonectens & SIO A2583 & JX078955 & JX078955 & JQ623495 & - \\
\hline $\begin{array}{l}\text { Dysponetus } \mathrm{sp} . \\
\text { HESIONIDAE }\end{array}$ & GB & EU555038 & EU555048 & EU555055 & - \\
\hline $\begin{array}{l}\text { Ophiodromus flexuosus } \\
\text { NEREIDIDAE }\end{array}$ & GB & DQ442592 & DQ442578 & AF221573 & - \\
\hline Ceratocephale loveni & GB & DQ442616 & DQ442614 & - & - \\
\hline $\begin{array}{c}\text { Ceratonereis longiceratophora } \\
\text { PHYLLODOCIDAE }\end{array}$ & GB & AB106251 & - & AY583701 & - \\
\hline Eulalia viridis & GB & AY996085 & AY996064 & AY996122 & - \\
\hline Notophyllum foliosum & GB & AY996079 & DQ779627 & AY996117 & DQ779748 \\
\hline
\end{tabular}




$$
\begin{aligned}
\mathrm{p} & =\text { palps } \\
\mathrm{pf} & =\text { posterior fragment } \\
\mathrm{St} & =\text { station } \\
\mathrm{vc} & =\text { ventral cirrus }
\end{aligned}
$$

\title{
Repositories
}

DBUA $=$ Biological Research Collection of Marine Invertebrates, Departamento de Biologia, Universidade de Aveiro, Portugal

NHMUK = Natural History Museum, London, UK

\section{Results}

\section{Phylogenetic analysis}

Eight chrysopetalid specimens belonging to four different species were examined in this study. Arichlidon reyssi, Dysponetus caecus and D. profundus are free-living forms found mostly in areas characterized by the presence of biogenic substrates (e.g., cold water corals, inactive carbonate chimneys, sunken wood). A brief description of each species is included here and any discrepancies regarding the original description are discussed. Craseoschema thyasiricola gen. et sp. nov. is a new calamyzin, the commensal of a chemosynthesis-based bivalve, for which a full description, drawings and images are given.

Fifteen specimens, belonging to the symbiotic calamyzin Natsushima bifurcata, were already reported in a previous paper (Ravara et al. 2007), in which the morphological similarity between the Atlantic and Japanese specimens is discussed. Some updated remarks regarding the host species are given in the present study.

Nine of the 17 nominal calamyzin genera, including symbionts and free-living forms, together with the new taxon were included in a maximum likelihood phylogenetic analysis aiming to determine the position of the new genus in relation to other calamyzin genera (Fig. 2). Results obtained after analysing the partitions independently and the combined data set, respectively, show equivalent topologies. The differences between results from each independent partition and the combined data set are explained by the differences in the terminals and sequences included in each case (see Table 2). Despite the low support values of the tree in the combined analysis (Fig. 2), the new genus is placed within the clade of symbiotic taxa close to the genera Calamyzas, Natsushima Miura \& Laubier, 1990 and the recently described Spathochaeta Jimi et al., 2019.

\section{Systematics}

\author{
Phylum Annelida Lamarck, 1809 \\ Class Polychaeta Grube, 1850 \\ Family Chrysopetalidae Ehlers, 1864 \\ Subfamily Chrysopetalinae Ehlers, 1864 \\ Genus Arichlidon Watson Russell, 1998
}

Arichlidon reyssi (Katzmann, Laubier \& Ramos, 1974)

Bhawania reyssi Katzmann, Laubier \& Ramos, 1974: 313, fig. 1 (type locality: Adriatic Sea, 51-77 m; other localities: Catalan and Banyuls-sur-Mer coasts, $10 \mathrm{~m}$ ).

Paleanotus heteroseta - Rullier 1964: 142 (Cape Verde Islands, 20-100 m). [not Hartman, 1945] 
Arichlidon reyssi - Watson Russell 1998: 159, figs 4, 6 (Mediterranean, Red Sea, intertidal to 3947 m). - Watson et al. 2014: 317, fig. 4 (Senghor Seamount, Cape Verde Archipelago, 1000$1651 \mathrm{~m})$.

\section{Material examined}

SPAIN - Bay of Biscay 1 af, 1 pf; tributary of Cap Breton Canyon; $43^{\circ} 31.74^{\prime} \mathrm{N}, 02^{\circ} 45.60^{\prime} \mathrm{W} ; 221 \mathrm{~m}$; St M84-5_633; DBUA 0002276.01 - 1 af; tributary of Cap Breton Canyon; $43^{\circ} 31.68^{\prime}$ N, $02^{\circ} 45.48^{\prime}$ W; 214 m; St M84-5_677; DBUA 0002276.02.

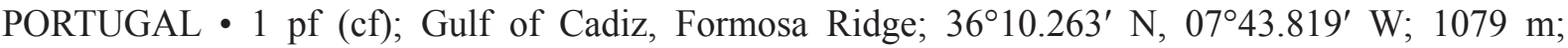
St TTR12_AT388; DBUA 0000698.

\section{Description}

Both specimens from the Bay of Biscay are very small and extremely arched, and thus difficult to examine. The anterior fragment from station M84-5_633 (DBUA 0002276.01) has eleven chaetigers and measures approximately $1.17 \mathrm{~mm}$ long. Should the two fragments (anterior and posterior) belong to the same specimen, the total number of chaetigers would be 17 and the total length $1.94 \mathrm{~mm}$. Prostomium with two pairs of coalescent dark eyes. Indistinct paired structure present ventrally at mouth level. Palaeal notochaetae bright and translucent, covering entire body and forming an acute mid-dorsal ridge.

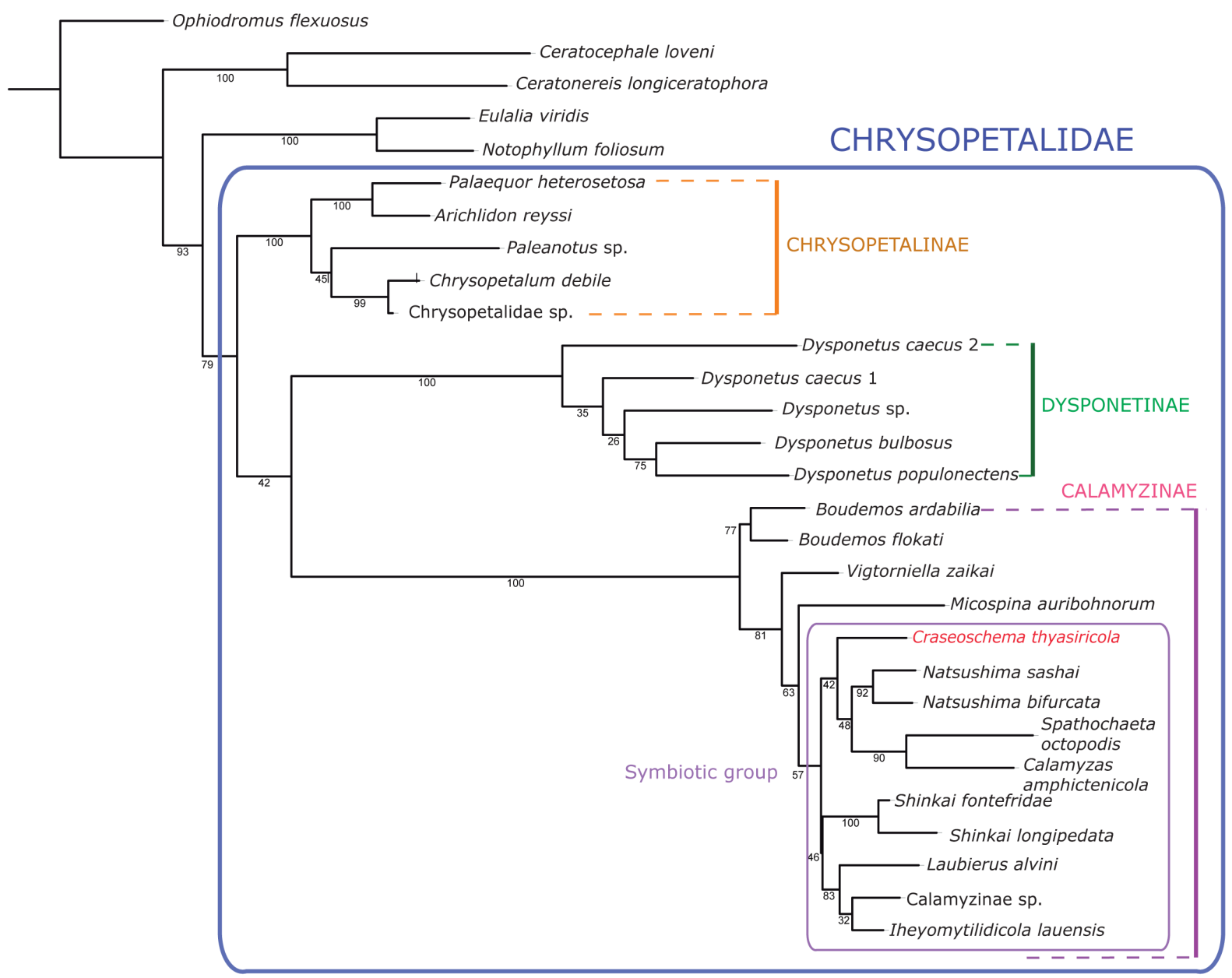

Tree scale: 0.1

Fig. 2. Maximum likelihood tree of the concatenated data set, including the genes COI, H3, 16S and 18S. Bootstrap support values are shown below the nodes. 
Paleae broadly rounded, distally with a small acute tip and strong serrate margins; dorsal surface with raised serrate ribs. Blades of compound neurochaetae long and spinigerous, in dorsalmost position becoming falcigerous and gradually shorter ventrally.

\section{Remarks}

Arichlidon reyssi has often been reported as occurring in large numbers at a given locality (e.g., Aguirrezabalaga et al. 1986, Cantabrian Sea, 100 m, numerous specimens; Watson Russell 1998, eastern Mediterranean, 196-199 m, 82 specimens; Watson et al. 2014, Senghor seamount, 102-133 m, 80 specimens). In the present study, only a couple of specimens were found at shelf-break depths in the Bay of Biscay and a dubious posterior fragment at a deeper station in the Gulf of Cadiz. These small and incomplete specimens possess lateralmost median paleae not clearly longer than the remaining ones, which is a distinguishing character for A. reyssi (Watson Russell 1998, 2000b). Apart from that, no other obvious morphological differences were found. The absence of tall lateralmost median paleae in some specimens was previously noted for the eastern Mediterranean, Red Sea and Egyptian populations, which were nonetheless considered as belonging to the same species (Watson Russell 1998). However, the known wide bathymetric range of this species suggests a possible complex of cryptic species in need of further study (see Watson et al. 2014).

\section{Ecology and distribution}

Arichlidon reyssi is distributed in the NE Atlantic from the Cantabrian Sea (Bay of Biscay) to the Cape Verde Archipelago, at 20-1651 m; in the Mediterranean from the Alboran Sea to the Levant Basin, from the intertidal to $3947 \mathrm{~m}$ (the deepest locations in the E Mediterranean); in the Red Sea from the intertidal to a depth of 757 m (Watson Russell 1998; San Martín 2004; Watson et al. 2014). Arichlidon reyssi usually occurs in hard substrates, e.g., coarse sediments with shell debris, rock, calcareous substrates, but also in mud at the deepest localities (Watson 1998; San Martín 2004). The material studied herein was collected together with samples of the scleractinian coral, Dendrophyllia cornigera (Lamarck, 1816), at the head of a Cap Breton Canyon tributary (Cantabrian Sea, Bay of Biscay) at 214-221 m and from inactive carbonate chimneys at Formosa Ridge (SW Iberian margin, Gulf of Cadiz) at $1079 \mathrm{~m}$.

\section{Subfamily Dysponetinae Aguado, Nygren \& Rouse, 2013 \\ Genus Dysponetus Levinsen, 1879}

Dysponetus caecus (Langerhans, 1880)

Chrysopetalum caecum Langerhans, 1880: 278, pl. 14, fig. 9 (type locality: Madeira Island).

Chrysopetalum caecum - Laubier 1964: 125, figs 1-2 (Mediterranean Sea, 32 m).

Dysponetus caecus - Dahlgren \& Pleijel 1995: 159, figs 2-3 (Scotland, Sweden and Denmark, intertidal to $85 \mathrm{~m}$ ). - Böggemann 2009: 283, figs 20-21 (Angola and Guinea Basins, 5048-5494 m). Watson et al. 2014: 315, fig. 3a-b (Senghor Seamount, $3241 \mathrm{~m}$ ).

\section{Material examined}

FRANCE 1 af; Bay of Biscay, Saint Nazaire Canyon; $46^{\circ} 14.22^{\prime}$ N, 04¹9.56' W; 755 m; St M845_690; DBUA 0002277.

MOROCCO - 2 af; Gulf of Cadiz, Mercator mud volcano; $35^{\circ} 17.916^{\prime}$ N, 06³8.709' W; 354 m; St 64PE284_12750W; DBUA 0001620.

\section{Description}

All three specimens examined are very small and incomplete; longest fragment nearly complete, with 22 chaetigers, $3.6 \mathrm{~mm}$ long (DBUA 0001620), in poor condition. Body semi-transparent, with orange intestine. Notochaetae long, bright and translucent, covering dorsum from chaetiger 8/9 in smaller 
fragments. Prostomium sub-quadrangular, without eyes; palps and antennae missing in all specimens. Elongate, single lobe present ventrally on posterior margin of mouth. Pharynx visible through body wall, extending to segment 7; jaws not visible. First segment reduced, with two pairs of tentacular cirri (only cirrophores present). Second segment with uniramous parapodia, notochaetae, dorsal cirri and ventral cirri. Following parapodia biramous, with well-developed chaetigerous lobes, dorsal cirri and ventral cirri. Notopodial lobes low, conical mounds. Neuropodial lobes cylindrical, elongate, much longer than notopodia. Dorsal and ventral cirri tapering to long and filiform tips, almost as long as chaetae; dorsal cirri longer than ventral cirri. Notochaetae spine-like, internally chambered, with two longitudinal rows of long alternating spinelets. Neurochaetae with internally chambered shafts and very finely serrated falcigerous blades with minute bidentate tips.

\section{Remarks}

This species was originally described from Madeira Island (Langerhans 1880) and was later reported from the Mediterranean Sea (Banyuls-sur-Mer; Laubier 1964). In the absence of extant type material, Dahlgren \& Pleijel (1995) designated a neotype from the Mediterranean Sea and further extended the geographical distribution of the species to the NW European margin. More recently, Böggemann (2009) and Watson et al. (2014) described the same species from deeper waters off W Africa. Watson et al. (2014) discussed some morphological differences between the NE Atlantic, Mediterranean Sea and Angola Basin abyssal specimens. According to these authors, the Senghor Seamount and Madeira Island specimens have moderate length palps comparing to the longer palps of the Mediterranean Sea specimens. Also, the Senghor Seamount specimens have biramous parapodia on segment 2 without ventral cirri, while the Mediterranean Sea and Angola Basin specimens have uniramous parapodia on segment 2, with notochaetae, dorsal cirri and ventral cirri. Furthermore, a marked increase of notochaetal length between chaetigers 9 and 13 was observed for the first time in Senghor Seamount specimens (Watson et al. 2014). In the specimens examined herein, palps are missing and segment 2 has uniramous parapodia with notochaetae, dorsal and ventral cirri, similar to the Mediterranean Sea specimens. As already mentioned by Watson et al. (2014), this taxon may be a complex of cryptic species and needs further revision, preferably with the inclusion of molecular data.

\section{Ecology and distribution}

Dysponetus caecus was previously recorded from shallow depths among sponges and kelp holdfasts from the intertidal to $85 \mathrm{~m}$ from S Sweden to Madeira Island, including N and W Scotland and N Denmark (Dahlgren \& Pleijel 1995) and in similar habitats from the Mediterranean Sea (Alboran Sea and Banyuls-sur-Mer; San Martín 2004). The species was reported from deeper waters ( $\sim 3000 \mathrm{~m})$ at Senghor Seamount, NW Africa, from fine clay sediments (Watson et al. 2014) and from muddy sand with shell and gravel in the Guinea, Angola and Cape Basins (5494 m; Böggemann 2009). The specimens studied here were found in Saint Nazaire Canyon (Bay of Biscay) (Fig. 1), in a cold-water coral environment at a depth of $755 \mathrm{~m}$, and in the Mercator MV (Gulf of Cadiz), in sunken wood colonization experiments densely colonised by Xylophaga dorsalis (W. Turton, 1819) at a depth of $354 \mathrm{~m}$ (Cunha et al. 2013a).

Dysponetus profundus Böggemann, 2009

Dysponetus profundus Böggemann, 2009: 288, figs 25-26 (Angola and Guinea Basins, 3991-5655 m).

\section{Material examined}

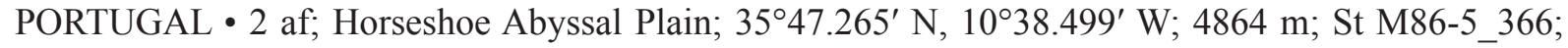
DBUA 0002278.

\section{Description}

Two tiny and incomplete specimens, with five chaetigers each (about $0.40 \mathrm{~mm}$ long). Notochaetae long, bright and translucent, covering dorsum from chaetiger 5. Prostomium rounded, without eyes. 
Palps and antennae globular. Pharynx visible through body wall, extending to segment 5 , with a pair of slender light brown stylets, visible through body wall. First segment reduced, with two pairs of globular tentacular cirri. Following segments with biramous parapodia, noto- and neurochaetae. Notopodial lobes as low mounds. Neuropodial lobes cylindrical, larger than notopodia. Dorsal cirri globular on segment 2 (chaetiger 1), becoming elongated posteriorly. Ventral cirri missing in all parapodia. Notochaetae spine-like, robust, internally chambered, with two longitudinal rows of short alternating spinelets. Neurochaetae with internally chambered shafts and very finely serrated blades with minute bidentate tips; blades variable in length.

\section{Ecology and distribution}

Dysponetus profundus was originally described from the Angola and Guinea Basins, at depths of 3991$5655 \mathrm{~m}$ (Böggemann 2009). The specimens reported here were recovered in hemipelagic silty clay with foraminiferans collected from a topographic high in the vicinity of the SW Iberian margin fault lineaments (Hensen et al. 2015). The present study extends the geographical distribution of this species to the Horseshoe Abyssal Plain (SW Iberian margin; Fig. 1), at a depth of $4864 \mathrm{~m}$.

\section{Subfamily Calamyzinae Hartmann-Schröder, 1971 \\ Genus Natsushima Miura \& Laubier, 1990}

Natsushima bifurcata Miura \& Laubier, 1990

Natsushima bifurcata Miura \& Laubier, 1990: 322-323, fig. 2 (type locality: Sagami Bay, Japan, 1170 m; host: Acharax sp.).

Natsushima bifurcata - Miura \& Hashimoto 1996: 265-266 (Sagami Bay, 1114 m; host: Acharax johnsoni Dall, 1891). — Ravara et al. 2007: 96, fig. 1 (Gulf of Cadiz, 920-1105 m; host: Acharax sp.).

\section{Material examined}

MOROCCO - Gulf of Cadiz • 3 cs; Jesuz Baraza mud volcano; 35³5.439' N, 07²12.264' W; 1105 m; 9 Jul. 2002; inside mantle cavity of Acharax gadirae; St. TTR12_AT391; DBUA $00711 \bullet 1$ af(damaged); Yuma mud volcano; $35^{\circ} 24.973^{\prime} \mathrm{N}, 07^{\circ} 05.461^{\prime} \mathrm{W}$; $960 \mathrm{~m}$; 2 Aug. 2004; inside mantle cavity of Acharax gadirae; St TTR14_AT524; DBUA 00765 - 4 cs; Yuma mud volcano; $35^{\circ} 25.820^{\prime} \mathrm{N}, 07^{\circ} 06.330^{\prime} \mathrm{W}$; 1030 m; 29 May 2006; inside mantle cavity of Acharax gadirae; St TTR16_AT604; DBUA 00791.01

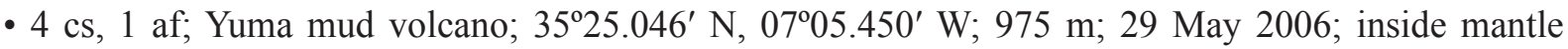
cavity of Acharax gadirae; St TTR16_AT605; DBUA 00791.02 - 2 cs; Ginsburg mud volcano; $35^{\circ} 22.677^{\prime} \mathrm{N}, 07^{\circ} 04.979^{\prime} \mathrm{W} ; 920 \mathrm{~m} ; 29$ May 2006; inside mantle cavity of Acharax gadirae; St TTR16_AT607; DBUA 00791.03.

\section{Remarks}

Ravara et al. (2007) reported this species from cold seeps in the Gulf of Cadiz (Jesus Baraza, Yuma and Ginsberg MVs). The specimens were found in the mantle cavity of Acharax sp., which was later described as a new species, Acharax gadirae Oliver, Rodrigues \& Cunha, 2011 (Bivalvia: Solemyidae) (Oliver et al. 2011). The bathymetric range of Acharax gadirae in the Gulf of Cadiz is 556-3902 m. However, only the populations from the mud volcanoes of the Western Moroccan field, located at depths of 920-1105 m, were infested by $N$. bifurcata. This species was originally found in the mantle cavity of Acharax johnsoni (Dall, 1891) from the Hatsushima and Okino-Yama cold seeps in Sagami Bay (E Pacific), at similar depths (1114-1170 m). Despite the great geographical distance, there were no substantial morphological differences between the specimens from the two localities that could justify the establishment of a new species. Aguado \& Rouse (2011) obtained a COI sequence from one of the 
specimens from the Gulf of Cadiz (GenBank accession number JF304492). However, the preservation of the Japanese specimens did not allow DNA analysis, and thus a molecular comparison was not possible.

\section{Ecology and distribution}

East Pacific (Sagami Bay, Japan) and NE Atlantic (Gulf of Cadiz), living inside the mantle cavity of chemosynthesis-based bivalves of the genus Acharax, from cold seeps at depths of 920-1170 m (Miura \& Laubier 1990; Ravara et al. 2007).

$$
\begin{aligned}
& \text { Craseoschema Ravara \& Aguado gen. nov. } \\
& \text { urn:1sid:zoobank.org:act:28EA7F9D-30BF-408B-A133-2B2F38EA924E }
\end{aligned}
$$

\section{Type species}

Craseoschema thyasiricola gen. et sp. nov., by present designation and monotypy.

\section{Diagnosis}

Body long, tapering posteriorly, arched dorsally and flattened ventrally. Prostomium short, with one pair of cirriform antennae with basal swelling and one pair of pad-like palps, without eyes. First segment fused with prostomium, with dorsal and ventral cirri, neuroacicula and neuropodial chaetae. Anterior parapodia with dorsal and ventral cirri and compound neurochaetae. Median and posterior parapodia subbiramous, with dorsal and ventral cirri, simple notochaetae and compound neurochaetae. All chaetae with modified tips. Pygidium cylindrical, without appendages.

\section{Etymology}

The genus name is a combination of the Greek words 'krasis', meaning 'mixture' or 'combination', and 'schema', meaning 'characteristic' or 'figure', in an allusion to the mixed characteristics from the symbiont and free-living forms.

\section{Remarks}

The subfamily Calamyzinae includes symbiont and free-living forms, the majority of which are associated with chemosynthetic environments. These forms have different morphological characteristics in a clear adaptation to their life style. The new genus is based on a specimen found inside a thyasirid bivalve and presents all the characteristics of a symbiont form (arched body, poorly developed notopodia with short dorsal cirri, neurochaetae with modified tips, absence of pygidial cirri), but also some characteristics of the free-living forms (presence of pad-like palps, notochaetae and compound neurochaetae). This particular combination of characteristics makes it different from all other genera within Calamyzinae except for a recently described new genus, Spathochaeta Jimi et al., 2019, found on the body surface of an octopus from the Kumano Sea, Japan (Jimi et al. 2019). Spathochaeta and Craseoschema gen. nov. present a similar composition of characters: arched body, a pair of ventrally placed palps, notochaetae with modified tips, compound neurochaetae and pygidial cirri absent. However, they differ by the presence in Spathochaeta of a well-developed dorsal lobe in the notopodia and spinigerous neurochaetae, rather than falcigerous with modified tips. The genus Calamyzas, parasites of ampharetid polychaetes, also possesses compound neurochaetae but notochaetae are absent and the parapodia of the first chaetiger are reduced to a pair of ventral cirri. Craseoschema gen. nov. is similar to the freeliving genera (Vigtorniella Kiseleva, 1996, Boudemos Watson et al., 2016 and Micospina Watson et al., 2016) in the possession of notochaetae and compound neurochaetae, but differs in details of noto- and neurochaetal morphology and in lacking tentacular and anal cirri. The separation of Craseoschema gen. nov. from the other Calamyzinae is also evident in the phylogenetic analysis presented (Fig. 2). Craseoschema gen. nov. is placed together with the symbiont forms of Calamyzinae in a monophyletic group, although this is not strongly supported (Fig. 2). 
Craseoschema thyasiricola Ravara \& Aguado sp. nov. urn:1sid:zoobank.org:act:146CA9DD-11B3-46F0-81A8-2E6B085458C0

Figs $3-5$

\section{Diagnosis}

Chaetous neuropodia and dorsal and ventral cirri present on the first segment. Notopodial lobes poorly developed. Notochaetae stick-like, with denticulated tips. Neurochaetae compound, with serrated blades and denticulated tips.

\section{Etymology}

The species name is derived from the host bivalve genus Thyasira, with the Latin suffix -cola denoting 'inhabiting'.

\section{Material examined}

\section{Holotype}

PORTUGAL - 1 af, 1 pf, several mf; Gulf of Cadiz, Carlos Ribeiro mud volcano; $35^{\circ} 47.238^{\prime} \mathrm{N}$, $08^{\circ} 25.272^{\prime} \mathrm{W} ; 2200 \mathrm{~m}$; specimen found inside mantle cavity of Thyasira vulcolutre (Bivalvia, Thyasiridae); St TTR16_AT615; ANEA NHMUK 2019.7339 • 2 mf; same locality; 1 slide and 1 SEM stub; DBUA 0002275.

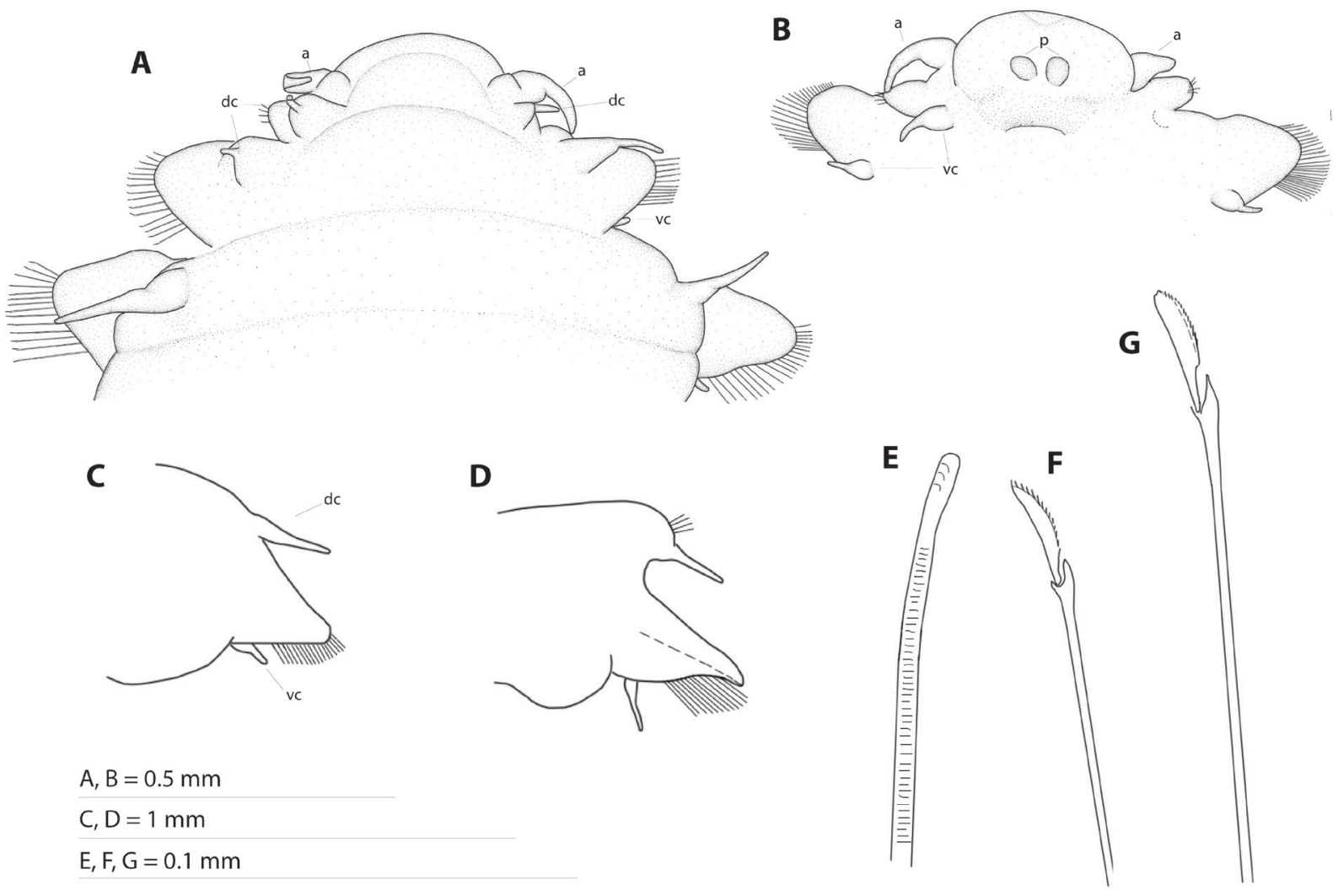

Fig. 3. Craseoschema thyasiricola gen. et sp. nov. Line drawings. A. Anterior end, dorsal view. B. Prostomium, ventral view. C. Third parapodium, posterior view. D. Median parapodium, posterior view. E. Notochaeta from median parapodium. F. Ventralmost neurochaeta from the second parapodium. G. Dorsalmost neurochaeta from median parapodium. 


\section{Description}

Only one fragmented specimen was found, inside the mantle cavity of a bivalve of the species Thyasira vulcolutre Rodrigues \& Oliver, 2008. The anterior fragment has three chaetigers, the posterior nine chaetigers; largest median fragment with seventeen chaetigers, $5.82 \mathrm{~mm}$ long. Body elongate, tapering at anterior and posterior ends, arched dorsally and flattened ventrally, rectangular in crosssection (Fig. 5A). Colour in ethanol white. Prostomium very short, broadly rounded anteriorly, fused to first chaetiger (Figs 3A, 4A). Eyes absent. Paired antennae cirriform, with basal swelling, inserted dorsolaterally (Figs 3A, 4A). Palps as low mound structures, inserted ventrally just anterior to mouth (Fig. 3B). Pharynx strongly muscularised; jaws not examined (specimen not dissected in order to keep its integrity as holotype). Parapodia much shorter on first segment than on following ones (Fig. 3A-B). Dorsal and ventral cirri digitiform, present from first chaetiger. Notopodia clearly present from segment 4, rounded, with straight notoacicula and dorsal cirri inserted distally; neuropodia much longer and conical, neuroacicula with bent tips (Fig. 4D), ventral cirri inserted close to base (Figs 3C-D, 4B, $5 B)$.

Notochaetae simple, stick-like, laddered basally, with a few rows of small spines subdistally, and ending in blunt and slightly curved tips with several denticles (only visible in SEM; Figs 3E, 5C-D); absent in first three segments, up to 15 present in median and posterior segments; a single notochaeta in last segments. Neurochaetae compound falcigers, with long, laddered shafts and short, finely serrated blades (Figs 3F-G, 4E, 5E-H). Neurochaetae longer in dorsalmost position, gradually shortening ventrally, and present in greater numbers than notochaetae in all segments. Blades of dorsalmost neurochaetae with two rows of longitudinal spines and numerous denticles distally, with a worn appearance under

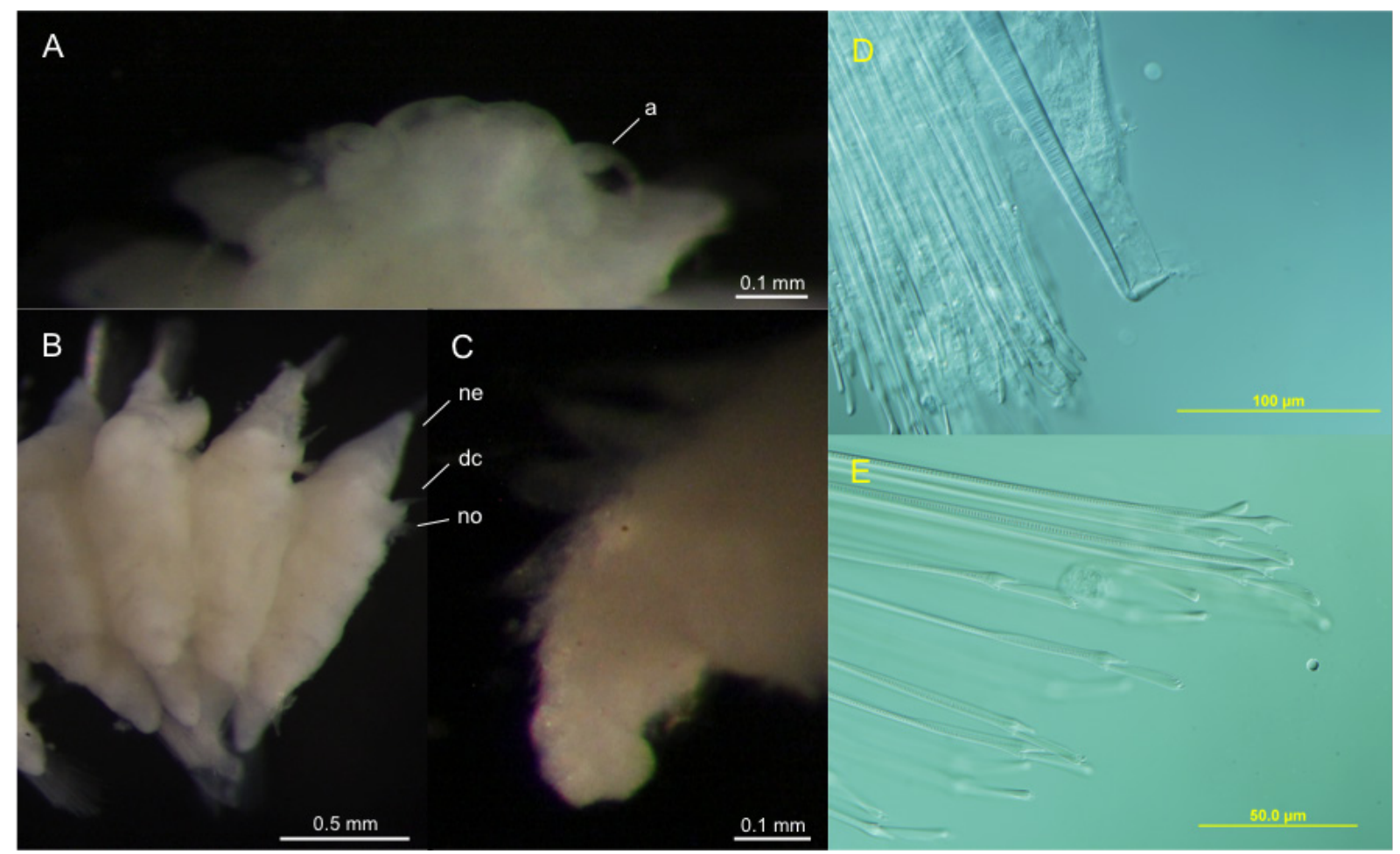

Fig. 4. Craseoschema thyasiricola gen. et sp. nov. Stereo (A-C) and compound (D-E) microscope images. A. Prostomium, dorsal view. B. Median region, dorsal view. C. Pygidium, ventral view. D. Neuroacicula of a median parapodium. E. Neurochaetae of a median parapodium. 
compound microscope (Fig. 5E-F); blades of ventralmost neurochaetae with longer spines arranged in two longitudinal rows that are wider apart distally, resembling a spaghetti-spoon (Fig. 5G-H). Pygidium button-like, with terminal anus and no appendages (Fig. 4C).
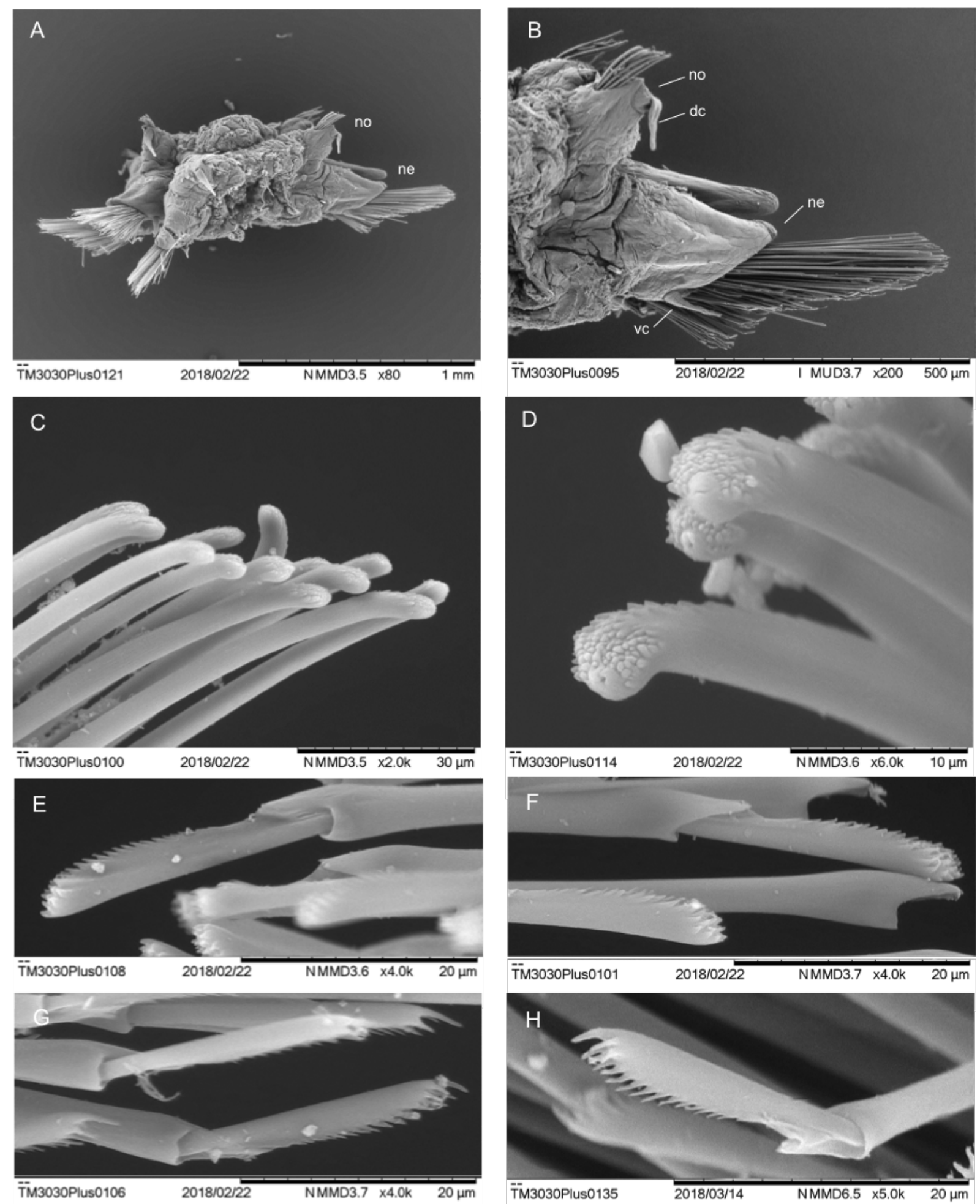

Fig. 5. Craseoschema thyasiricola gen. et sp. nov. SEM images. A. Fragment from median region, posterior view. B. Median parapodium, posterior view. C. Notochaetae of median parapodium. D. Notochaetal tips. E-F. Dorsalmost neurochaetae. G-H. Ventralmost neurochaetae. 


\section{Remarks}

Carlos Ribeiro is the deepest and most active mud volcano among the five mud volcanoes from where chrysopetalid specimens are recorded in this study. Two species of thyasirid bivalves, Thyasira vulcolutre (3 specimens) and T. obsoleta (Verrill \& Bush, 1898) (1 specimen), were collected in the crater of this mud volcano (Rodrigues et al. 2008), but only one large specimen of T. vulcolutre was infested. This thyasirid species was also reported to occur in higher abundance on Captain Arutyunov MV (37 spms) and Sagres MV (32 spms). These mud volcanoes were also reported as active cold seeps in the deepwater field, but none of the small-sized specimens collected from them (at depths of $1321 \mathrm{~m}$ and $1562 \mathrm{~m}$, respectively) were infested. In the Gulf of Cadiz, Thyasiridae are represented by nine species collected from 10 different mud volcanoes, but only two are recognized as chemosymbiotic and both occur in MVs of the Deep Field: Thyasira vulcolutre (Captain Arutyunov, Sagres and Carlos Ribeiro MVs) and Spinaxinus sentosus Oliver \& Holmes, 2006 (Captain Arutyunov MV) (Rodrigues et al. 2013). Another two species are mixotrophic and occur across a wider bathymetric range: Axinulus croulinensis (Jeffreys, 1847) (Mercator, Meknès, Captain Arutyunov, Bonjardim and Porto MVs; 350-3900 m) and Thyasira granulosa (Monterosato, 1874) (Mercator, Meknès, Chechaouen, Darwin and Captain Arutyunov MVs; 350-1321 m) (Rodrigues et al. 2013 and unpublished data). Except for the large specimen of T. vulcolutre from Carlos Ribeiro MV, all the other thyasirid specimens were not infested.

\section{Ecology and distribution}

NE Atlantic (Gulf of Cadiz), on Carlos Ribeiro MV, at a depth of $2200 \mathrm{~m}$. Found in the mantle cavity of the chemosynthesis-based bivalve Thyasira vulcolutre Rodrigues \& Oliver, 2008.

\section{Discussion}

The family Chrysopetalidae was originally named after the internally camerated, flattened and brightcoloured notochaetae (paleae) that cover the dorsum of the free-living taxa belonging to the subfamily Chrysopetalinae. These chaetae are believed to be defensive and protective for planktonic larvae and adults that swim in the water column (Watson Russell 1997; Watson et al. 2016). However, a substantial number of species in this family, belonging to the subfamilies Dysponetinae and the recently allocated Calamyzinae (formerly Nautiliniellidae), lack dorsal paleae (Aguado et al. 2013). In all Dysponetinae and in the free-living species of Calamyzinae, the notochaetae are thin spines, rounded in cross section. While most symbiotic Calamyzinae lack notochaetae, Spathochaeta and Craseoschema gen. nov. possess stout notochaetae, much thicker than in free-living forms. The neurochaetae of most symbiotic Calamyzinae (e.g., in commensal forms inhabiting the mantle cavity of bivalves) are simple, with modified tips, suggesting an adaptation to anchor in or slide on the soft tissues of their hosts. The exceptions are the external parasitic species Calamyzas amphictenicola, the external symbiotic species Spathochaeta octopodis Jimi et al., 2019 and Craseoschema thyasiricola gen. et sp. nov., which have compound neurochaetae, as all the free-living forms. Similarly to the Chrysopetalinae, both the notoand neurochaetae of the Dysponetinae and the free-living Calamyzinae are internally camerated. The apparent loss of cameration in the chaetae of adult symbiont calamyzins has been hypothesised to be a result of the intimate association with their hosts and subsequent reduced mobility (Watson et al. 2016). However, it is possible that the cameration has been overlooked in the descriptions of symbiotic calamyzins. Craseoschema thyasiricola gen. et sp. nov. possesses camerated noto- and neurochaetae.

The relationship between chaetal morphology and different host types is not yet fully understood. However, there are marked morphological affinities among worm species associated with bivalves of the same family, which suggest a possible coevolution of the worms and their hosts (see also Aguado \& Rouse 2011). The genera Vesicomyicola Dreyer et al., 2004, Shinkai Miura \& Laubier, 1990 and Nautiliniella Miura \& Laubier, 1990, associated with the family Vesicomyidae, possess neuropodial hooks that may vary from simple to trifurcate. The neurochaetae of species of Natsushima, associated with 
the family Solemyidae, include many bidentate chaetae along with the simple hooks. Iheyomytilidicola Miura \& Hashimoto, 1996 and Laubierus Blake, 1993, associated with the family Mytilidae, have a neurochaetal combination similar to that in Natsushima, but with sigmoid instead of bidentate chaetae. Members of the genus Mytilidiphila Miura \& Hashimoto, 1993 also associated with Mytilidae, only have simple hooks that are nevertheless very slender and similar to the sigmoid chaetae. The neurochaetae of the genera Thyasiridicola Miura \& Hashimoto, 1996 and Petrecca Blake, 1990 associated with the family Thyasiridae, consist only of simple hooks. However, the new genus described here falls outside this pattern. Although also associated with thyasirid bivalves, Craseoschema gen. nov. does not have simple hooks, but displays compound neurochaetae with multidentate blades.

Free-living chrysopetalids are often found in association with biogenic substrates such as sea grass and algal mats, coral reefs, sponges and invertebrate tube aggregations. There are also records of species found in experimental sunken wood. Turner (1978) reported on a Chrysopetalinae (Strepternos didymopyton Watson Russell, 1991) feeding on Xylophaga Turton, 1822 (Bivalvia), and herein we report on a species of Dysponetinae (Dysponetus caecus) found in wood also densely colonized by Xylophaga. In whale falls, methane seeps and anoxic basins, free-living forms of Calamyzinae may occur in very high abundance, apparently feeding on the bacterial mats or on dissolved material emanating from decaying organic substrata; they are considered as enrichment bacteriovore opportunists (Dahlgren et al. 2004; Wiklund et al. 2009; Watson et al. 2016). It is also in chemosynthetic environments that the host bivalves of the commensal forms occur. The number of described calamyzin species has grown substantially in the past few years, mainly due to the increasing number of studies on deep-sea chemosynthetic environments. However, the number of records for each species is still low and it is likely that their known distribution is biased by the geographic incidence of the studies on cold seeps. Compared to most cold-seep regions, which often occur at restricted bathymetric ranges along continental margins, the Gulf of Cadiz encompasses a very extensive (in terms of total area and bathymetry) cold-seepage field resulting from its long geologic history and complex geodynamic setting (Cunha et al. 2013b). This circumstance allowed us to observe a pattern that has not been reported for other calamyzin species, i.e., the two symbiotic species from the Gulf of Cadiz (Natsushima bifurcata and Craseoschema thyasiricola gen. et sp. nov.) present much narrower bathymetric distributions than their bivalve hosts (Acharax gadirae and Thyasira vulcolutre, respectively).

Overall, there is still little knowledge of the life history of Chrysopetalidae and especially of the behavioural interactions of symbiont calamyzins and their hosts. The low number of records of calamyzins also biases our current knowledge of the specificity of these relationships, with most species reported as being obligate symbionts and involved with only one host species (Martin \& Britayev 2018). While feeding on host pseudofaeces, mucus and gametes was hypothesized for obligate symbiont calamyzins (Becker et al. 2013), the small pair of stylet jaws, recently discovered in Shinkai longipedata Miura \& Ohta, 1991, suggests that this species, initially classified as a commensal, may prey on the tissues of its host (Watson \& Faulwetter 2017). Stylet jaws are also present in some free-living calamyzins such as Vigtorniella zaikai (Kiseleva, 1992) and Boudemos flokati Dahlgren et al., 2004 (Watson et al. 2016), but these minute structures may have been overlooked or not examined in past nautiliniellid studies or the specimens may not have been dissected in order to retain their integrity as holotypes (e.g., Jimi et al. 2019; this study). When jaws are inferred as absent, these species are then provisionally classified as commensals. Data on infestation rates and timing are also often lacking. The infestation rates may vary from one to several worms per bivalve, depending on the host size (Aguado \& Rouse 2011). However, it is not clear when in the polychaete's life cycle the infestation occurs, and that may also cast some doubts on the obligatoriness of some relationships.

The use of molecular data is crucial not only to confirm the identity of new taxa, but also to assess their position within the family and to unravel doubts regarding potentially cryptic species such as 
Arichlidon reyssi and Dysponetus caecus, as mentioned in the systematic section. The phylogenetic analysis included here assigns the three calamyzin genera with mixed characteristics of free-living and symbiont forms, Craseoschema gen. nov., Spathochaeta and Calamyzas, to the same clade (Fig. 2). In this clade, the two external symbiotic forms, Spathochaeta and Calamyzas, are linked together. Also the genera Laubierus and Iheyomytilidicola, both associated with the bivalve family Mytilidae, are assigned to the same clade. A similar result is presented in Watson et al. (2016) and Jimi et al. (2019). Unfortunately, molecular data are not available for most species of Calamyzinae, which is needed in order to assess the relationships between all the genera that infest the same bivalve family, in this case the relations between Craseoschema gen. nov. and the 'sibling' thyasirid symbionts.

\section{Acknowledgements}

Thanks are due to the chief scientists, scientific participants and crew of the cruises TTR12, 14 and 16 (RV Prof. Logachev, Training Through Research program, IOC-UNESCO), JC10 and 64PE284 (RRV James Cook and RV Pelagia, respectively, project CHEMECO), M84-5 and M86-5 (RV Meteor, project HERMIONE and SWIMGLO, respectively). Special thanks to Sandra Calado (Universidade de Aveiro) for her assistance with the compound microscope imaging, critical point drying and coating of the specimens used for SEM. We are also thankful to Greg Rouse for discussing and clarifying the differences between the 18S sequences of Micospina auribohnorum JX078941.1 and KU057928 available from Genbank. Financial support was provided by CESAM (UID/AMB/50017/2019) and by FCT/MCTES (Fundação para a Ciência e a Tecnologia/Ministério de Ciência, Tecnologia e Ensino Superior) through national funds. AR was supported by a postdoctoral grant (SFRH/BPD/112408/2015) from FCT co-financed by ESF (European Science Foundation) and MEC (Ministério da Fundação e Ciência). CR and LG were supported by postdoctoral grants, SFRH/BPD/107805/2015 and SFRH/ BPD/96142/2013, respectively. This study is a contribution of the "Macroevolutionary Transitions in Syllidae" Project (CGL2015-63593-P), supported by MINECO/FEDER (Ministério de Economia y Competitividad/Fondo Europeo de Desarrollo Regional) and European Union funds (PI: MTA).

\section{References}

Aguado M.T. \& Rouse G. 2011. Nautiliniellidae (Annelida) from Costa Rican cold seeps and a western Pacific hydrothermal vent, with description of four new species. Systematics and Biodiversity 9 (2): 109-131. https://doi.org/10.1080/14772000.2011.569033

Aguado M.T., Nygren A. \& Rouse G. 2013. Two apparently unrelated groups of symbiontic annelids, Nautiliniellidae and Calamyzidae (Phyllodocida, Annelida), are a clade of derived chrysopetalid polychaetes. Cladistics 29: 610-628. https://doi.org/10.1111/cla.12011

Aguirrezabalaga F., Altuna A., Arraras M. D., Miguel I., Romero A., Ruiz de Ocenda M. J., San Vicente D. \& Ibañez M. 1986. Contribucion al conocimiento de la fauna marina en la costa vasca. IV. Lurralde 9: 133-158.

Becker E.L., Cordes E.E., Macko S.A., Lee R.W. \& Fisher C.R. 2013. Using stable isotope compositions of animal tissues to infer trophic interactions in Gulf of Mexico lower slope seep communities. PLoS ONE 8: e74459. https://doi.org/10.1371/journal.pone.0074459

Böggemann M. 2009. Polychaetes (Annelida) of the abyssal SEAtlantic. Organisms Diversity \& Evolution 9 (4-5): 252-428. Available from http://www.sciencedirect.com/science/journal/14396092 [accessed 5 Jul. 2019].

Carr C.M., Hardy S.M., Brown T.M., Macdonald T.A. \& Hebert P.D.N. 2011. A tri-oceanic perspective: DNA barcoding reveals geographic structure and cryptic diversity in Canadian polychaetes. PLoS ONE 6: e22232. https://doi.org/10.1371/journal.pone.0022232 
Colgan D.J., Ponder W.F. \& Eggler P.E. 2000. Gastropod evolutionary rates and phylogenetic relationships assessed using partial 28S rDNA and histone H3 sequences. Zoologica Scripta 29 (1): 29-63.

https://doi.org/10.1046/j.1463-6409.2000.00021.x

Cunha M.R., Matos F.L., Génio L., Hilário A., Moura C.J., Ravara A. \& Rodrigues C.F. 2013a. Are organic falls bridging reduced environments in the deep sea? - Results from colonization experiments in the Gulf of Cadiz. PLoS One 8 (10): e76688. https://doi.org/10.1371/journal.pone.0076688

Cunha M.R., Rodrigues C.F., Génio L., Hilário A., Ravara A. \& Pfannkuche O. 2013b. Macrofaunal assemblages from mud volcanoes in the Gulf of Cadiz: abundance, biodiversity and diversity partitioning across spatial scales. Biogeosciences 10: 2553-2568. https://doi.org/10.5194/bg-10-2553-2013

Dahlgren T.G. \& Pleijel F. 1995. On the generic allocation of Chrysopetalum caecum Langerhans, 1880 (Polychaeta, Chrysopetalidae). Mitteilungen aus dem Hamburgischen Zoologischen Museum und Institut 92: 159-173. Available from https://www.researchgate.net/publication/284221312 [accessed 5 Jul. 2019].

Dahlgren T.G., Glover A.G., Baco A. \& Smith C.R. 2004. Fauna of whale falls: systematics and ecology of a new polychaete (Annelida: Chrysopetalidae) from the deep Pacific Ocean. Deep-Sea Research I 51: 1873-1887. https://doi.org/10.1016/j.dsr.2004.07.017

Dreyer J., Miura T. \& Van Dover C.L. 2004. Vesicomyicola trifurcatus, a new genus and species of commensal polychaete (Annelida: Polychaeta: Nautiliniellidae) found in deep-sea clams from the Blake Ridge cold seep. Proceedings of the Biological Society of Washington 117 (1): 106-113. Available from http://biostor.org/reference/81342 [accessed 5 Jul. 2019].

Hensen C., Scholz F., Nuzzo M., Valadares V., Gràcia E., Terrinha P., Liebetrau V., Kaul N., Silva S., Martínez-Loriente S., Bartolome R., Piñero E., Magalhães V.H., Schmidt M., Weise S.M., Cunha M., Hilário A., Perea H., Rovelli L. \& Lackschewitz K. 2015. Strike-slip faults mediate the rise of crustalderived fluids and mud volcanism in the deep sea. Geology 43 (4): 339-342.

https://doi.org/10.1130/G36359.1

Jimi N., Moritaki T. \& Kajihara H. 2019. Polychaete meets octopus: symbiotic relationship between Spathochaeta octopodis gen. et sp. nov. (Annelida: Chrysopetalidae) and Octopus sp. (Mollusca: Octopodidae). Systematics and Biodiversity 17 (1): 1-6.

https://doi.org/10.1080/14772000.2018.1520753

Katoh K., Misawa K., Kuma K. \& Miyata T. 2002. MAFFT: a novel method for rapid multiple sequence alignment based on fast Fourier transform. Nucleic Acids Research 30: 30593066.

Available from https://www.ncbi.nlm.nih.gov/pubmed/12136088 [accessed 5 Jul. 2019].

Katzmann W., Laubier L. \& Ramos J. 1974. Une nouvelle espèce Mediterranéenne de Chrysopetalidae (Annélides Polychètes). Annalen des Naturhistorischen Museums in Wein 78: 313-317.

Kück P. \& Longo G.C. 2014. FASconCAT-G: extensive functions for multiple sequence alignment preparations concerning phylogenetic studies. Frontiers in Zoology 11: e81.

https://doi.org/10.1186/s12983-014-0081-x

Langerhans P. 1880. Die Wurmfauna Madeiras. II. Zeitschrift für wissenschaftliche Zoologie 33 (1-2): 271-316. Available from https://biodiversitylibrary.org/page/45632728 [accessed 5 Jul. 2019].

Laubier L. 1964. Contribution à la faunistique du coralligène. VI. Présence de Chrysopetalum caecum Langerhans dans l'endofaune coralligène. Vie et Milieu 15 (1): 125-138.

Martin D. \& Britayev T.A. 1998. Symbiotic polychaetes: review of known species. Oceanography and Marine Biology: An Annual Review 36: 217-340.

Available from https://core.ac.uk/download/pdf/36049433.pdf [accessed 5 Jul. 2019]. 
Martin D. \& Britayev T.A. 2018. Symbiotic polychaetes revisited: an update of the known species and relationships (1998-2017). Oceanography and Marine Biology: An Annual Review 56: 371-448. Available from http://hdl.handle.net/10261/171832 [accessed 5 Jul. 2019].

Miura T. \& Hashimoto J. 1996. Nautiliniellid polychaetes living in the mantle cavity of bivalve molluscs from cold seeps and hydrothermal vents around Japan. Publications of the Seto Marine Biological Laboratory 37 (3-6): 257-274. Available from http://hdl.handle.net/2433/176264 [accessed 5 Jul. 2019].

Miura T. \& Laubier L. 1990. Nautiliniellid polychaetes collected from the Hatsushima cold-seep site in Sagami Bay with descriptions of new genera and species. Zoological Science 7: 319-325. Available from https://biodiversitylibrary.org/page/40503880 [accessed 5 Jul. 2019].

Oliver G., Rodrigues C.F. \& Cunha M.R. 2011. Chemosymbiotic bivalves from the mud volcanoes of the Gulf of Cadiz, NE Atlantic, with descriptions of new species of Solemyidae, Lucinidae and Vesicomyidae. Zookeys 113: 1-38. https://doi.org/10.3897/zookeys.113.1402

Ravara A., Cunha M.R. \& Rodrigues C. 2007. The occurrence of Natsushima bifurcata (Polychaeta: Nautiliniellidae) in Acharax hosts from mud volcanoes in the Gulf of Cadiz (south Iberian and north Moroccan margins). Scientia Marina 71 (1): 95-100.

Available from http://scimar.icm.csic.es/scimar/index.php/secId/6/IdArt/3300/ [accessed 5 Jul. 2019].

Read G. \& Fauchald K. (eds) 2018. World Polychaeta Database. Chrysopetalidae Ehlers, 1864. Available from http://www.marinespecies.org/polychaeta/aphia.php? $\mathrm{p}=$ taxdetails\&id=944 [accessed 9 Apr. 2018].

Rodrigues C.F., Oliver P.G. \& Cunha M.R. 2008. Thyasiroidea (Mollusca: Bivalvia) from the mud volcanoes of the Gulf of Cadiz (NE Atlantic). Zootaxa 1752: 41-56.

Available from https://www.mapress.com/j/zt/article/view/4731 [accessed 5 Jul. 2019].

Rodrigues C.F., Hilário A. \& Cunha M.R. 2013. Chemosymbiotic species from the Gulf of Cadiz (NE Atlantic): distribution, life styles and nutritional patterns. Biogeosciences 10: 2569-2581.

https://doi.org/10.5194/bg-10-2569-2013

Rullier F. 1964. Résultats scientifiques des campagnes de la "Calypso". Campagne aux îles du Cap Vert 1959. Annélides polychètes. Annales de l'Institut océanographique 41: 113-218.

San Martín G. 2004. Familia Chrysopetalidae Ehlers, 1864. In: Viéitez J.M., Alós C., Parapar J., Besteiro C., Moreira J., Nuñez J., Laborda J. \& San Martín G. (eds) Fauna Ibérica. Vol. 25: 105-209. Museo Nacional de Ciencias Naturales, CSIC, Madrid.

Sellanes J., Quiroga E. \& Neira C. 2008. Megafauna community structure and trophic relationships at the recently discovered Concepción Methane Seep Area, Chile, $\sim 36^{\circ}$ S. ICES Journal of Marine Science 65 (7): 1102-1111. https://doi.org/10.1093/icesjms/fsn099

Sjölin E., Erséus C. \& Källersjö M. 2005. Phylogeny of Tubificidae (Annelida, Clitellata) based on mitochondrial and nuclear sequence data. Molecular Phylogenetics and Evolution 35 (2): 431-441. https://doi.org/10.1016/j.ympev.2004.12.018

Stamatakis A. 2014. RAxML version 8: a tool for phylogenetic analysis and post-analysis of large phylogenies. Bioinformatics 30: 1312-1313. https://doi.org/10.1093/bioinformatics/btu033

Stamatakis A., Hoover P. \& Rougemont J. 2008. A rapid bootstrap algorithm for the RAxML web servers. Systematic Biology 57: 758-771. https://doi.org/10.1080/10635150802429642

Turner R.D. 1978. Wood, mollusks and deep-sea food chains. Bulletin of the American Malacological Union (1977): 13-19.

Watson C. \& Faulwetter S. 2017. Stylet jaws of Chrysopetalidae (Annelida). Journal of Natural History 51: 2863-2924. https://doi.org/10.1080/00222933.2017.1395919 
Watson C., Chivers A.J. Narayanaswamy B.E., Lamont P. \& Turnewitsch R. 2014. Chrysopetalidae (Annelida: Phyllodocida) from the Senghor Seamount, north-east Atlantic: taxa with deep-sea affinities and morphological adaptations. Memoirs of Museum Victoria 71: 311-325.

https://doi.org/10.24199/j.mmv.2014.71.24

Watson C., Carvajal J.I., Sergeeva N.G., Pleijel F. \& Rouse G.W. 2016. Free-living calamyzin chrysopetalids (Annelida) from methane seeps, anoxic basins, and whale falls. Zoological Journal of the Linnaen Society 177 (4): 700-719. https://doi.org/10.1111/zoj.12390

Watson Russell C. 1997. Patterns of growth and setal development in the deep-sea worm, Strepternos didymopyton (Polychaeta: Chrysopetalidae). Bulletin of Marine Science 60 (2): 405-426. Available from https://www.researchgate.net/publication/233662487 [accessed 5 Jul. 2019].

Watson Russell C. 1998. Description of Arichlidon new genus and two new species from Australia; Bhawania reyssi redescribed and assigned to Arichlidon (Chrysopetalidae: Polychaeta). The Beagle, Records of the Northern Territory Museum of Arts and Sciences 14: 159-176.

Watson Russell C. 2000a. Family Chrysopetalidae. In: Beesley P.L., Ross G.B. \& Glasby C.J. (eds) Polychaetes and Allies: The Southern Synthesis: 121-125. CSIRO Publishing, Melbourne.

Watson Russell C. 2000b. Description of a new species of Arichlidon (Chrysopetalidae: Polychaeta) from the West Atlantic and comparison with the East Atlantic species Arichlidon reyssi. Bulletin of Marine Science 67 (1): 465-477. Available from https://www.researchgate.net/publication/233573039 [accessed 5 Jul. 2019].

Watson Russell C. 2001. New genus and species of Chrysopetalidae (Polychaeta) from hydrothermal vents (south-western Pacific). The Beagle, Records of the Northern Territory Museum of Arts and Sciences 17: 57-66.

Wiklund H., Glover A.G., Johannessen P.J. \& Dahlgren T.G. 2009. Cryptic speciation at organic-rich marine habitats: a new bacteriovore annelid from whale-fall and fish farms in the North-East Atlantic. Zoological Journal of the Linnean Society 155 (4): 774-785.

https://doi.org/10.1111/j.1096-3642.2008.00469.x

Manuscript received: 25 March 2019

Manuscript accepted: 12 June 2019

Published on: 26 July 2019

Topic editor: Rudy Jocqué

Desk editor: Danny Eibye-Jacobsen

Printed versions of all papers are also deposited in the libraries of the institutes that are members of the EJT consortium: Muséum national d'Histoire naturelle, Paris, France; Meise Botanic Garden, Belgium; Royal Museum for Central Africa, Tervuren, Belgium; Royal Belgian Institute of Natural Sciences, Brussels, Belgium; Natural History Museum of Denmark, Copenhagen, Denmark; Naturalis Biodiversity Center, Leiden, the Netherlands; Museo Nacional de Ciencias Naturales-CSIC, Madrid, Spain; Real Jardín Botánico de Madrid CSIC, Spain; Zoological Research Museum Alexander Koenig, Bonn, Germany; National Museum, Prague, Czech Republic. 